\title{
The Pythagoreans in the light and shadows of recent research
}

\author{
PAPER PRESENTED AT \\ THE DONNERIAN SYMPOSIUM ON MYSTICISM, \\ SEP'TEMBER 7 th I 968
}

\section{By HOLGER THESLEFF}

It has been said" that "Pythagoras casts a long shadow in the history of Greek thought". Indeed, the shadow both widens and deepens spectacularly in course of time. He has not only been considered - on disputable grounds, as we shall see-as the first European mystic. No other personality of the Greco-Roman world (except Christ, and perhaps Alexander the Great) has been credited with such powers and all-round capacities. Since early Imperial times he has been represented as a man of divine origin, a saint, a sage, a prophet, and a great magician; a sportsman and an ascetic; a poet and prosewriter; a Dorian nationalist (though an Ionian by birth); an eminent mathematician, musician, astronomer, logician, rhetorician, and physician; a world-wide traveller; a founder of a religious sect, an ethical brotherhood, and a political community; a great metaphysician and teacher whose views of the universe, human society and the human soul deeply influenced not only Plato and Aristotle, but Herakleitos, Parmenides, Demokritos and, in short, all prominent thinkers; a preacher of universal tolerance, and-a good husband and father.

There can be seen occasional signs of a revival of Pythagoreanism at least from the Ist century A. D. onwards, ${ }^{2}$ and some authors of the Imperial age

\footnotetext{
1 Philip (below), p. 3.

${ }^{2}$ If Pseudo-Pythagorica are left out of account, the activity of the Sextii in Rome during the reign of Augustus is the first manifest sign. Cf. H. Thesleff, An introduction to the Pythagorean writings of the Hellenistic period (Acta Acad. Aboensis, Hum. XXIV. 3), Abo I961, p. 52 f. I have later expressed my doubts regarding the supposed Neopythagoreanism of Nigidius Figulus (ist century B.C.), see Gnomon 37, 1965, pp. 44 ff. H. Dörrie, $R E$ 23, I963, col. 269 f. suggests a "latentes Fortbestehen" of Pythagoreanism in the Hellenistic age.
} 
call themselves, or are called, Neopythagoreans (thus notably Nikomachos of Gerasa, Moderatos of Gadara, and Iamblichos of Syria). With Neoplatonism the traditions concerning Pythagorean doctrine and life passed on to the syncretism of late antiquity, to the Byzantine world, and to the Arabs, and went on inspiring the imagination of the learned and the dilettanti. The Pythagorean "renaissances" have continued in modern times. Even recently there have appeared some visionary but uncritical books on the "Pythagorean gospel", such as V. Capparelli's two expansive volumes on La sapienza di Pitagora (r94I and I944), J. Mallinger's Pythagore et les mystères (1944), and E. Bindel's Pythagoras (1962). In 1955 a 'World Congress of Pythagorean Societies' was held in Athens. As a symptom of man's needs and wishes the history of the Pythagorean "projection" is by no means negligible.

But what is the historical truth about Pythagoras? It is natural that the problem of disentangling the original body of Pythagoreanism from its later accretions has fascinated critical scholarship almost as much as the Pythagoreans have fascinated uncritical admirers. On the whole the view of scholars in the last 100 years has been dominated by Zeller's scepticism: a minimum of trust has been put in the sources, and a maximum of the legends and doctrines has been referred to the imagination of later eras. The scepticism culminated in Erich Frank's contention (1923) that most of the socalled Pythagoreanism is a creation by post-Platonic inventiveness. Some attempts to challenge Zeller's opinion on a wide front were made, notably by Armand Delatte and Augusto Rostagni, who have been followed, though with modifications of their views, by Burnet, Festugière, Boyancé, and some others. ${ }^{1}$ Mostly students of Pythagoreanism have been concerned with special points or aspects. Quite recently, however, in the 1960 's, there have appeared five books or sets of studies which aim at a reconsideration of the whole problem. All are works of serious original scholarship: it is interesting, perhaps irritating, to note that they are largely independent of each other, and that they differ widely in approach and conclusions. In fact they represent fairly well the different kinds of conception of Pythagoreanism current in the learned world since Zeller. I mean the following works:

${ }^{1}$ For references, see Burkert and von Fritz (below). 
Walter Burkert, Weisheit und Wissenschaft (1962). ${ }^{1}$ This is an immensely learned but difficult book. It will constitute the chief collection of the relevant references for many years to come. Burkert's approach is analytical and sceptical regarding the "rational" activities of the Pythagoreans: to him Pythagoras is a shamanist, and the contributions of the early Pythagorean school to philosophy and science are rather minimized.

W. K. C. Guthrie, A history of Greek philosophy, the section on the Pythagoreans in Vol. I (1962). ${ }^{2}$ This is an elegant presentation of the Pythagorean doctrines as a coherent philosophical system. Guthrie is less sceptical than Burkert. His book will probably be used as the standard work by the present generation of English-speaking scholars.

K. von Fritz and B. L. van der Waerden, the articles (or rather, monographs) on "Pythagoras" and "Pythagoreer" in $R E$ 23, $1963 .{ }^{3}$ von Fritz' approach is rather analytical, but his conception is more conventional than Burkert's. His speciality is the history of the Pythagorean school in the $5^{\text {th }}$ century в. с. His exposition suffers from some technical deficiencies, but it is likely to be much relied on by classical scholars. van der Waerden gives a clear-cut, but very optimistic and certainly too categorical reconstruction of Pythagorean science.

Cornelia J. de Vogel, Pythagoras and early Pythagoreanism (1966). ${ }^{4} \mathrm{~A}$ vigorous defence of the idea that Pythagoras was above all an educator and a teacher of advanced ethics. Owing to the reputation of its author, the book will probably exercise a wide influence also among non-specialists.

J. A. Philip's book appeared in the same year as de Vogel's (I966), and has an identical title, ${ }^{5}$ but is very different. To Philip, Pythagoras is not a shamanist, nor an ethical prophet, nor indeed a mathematician, but essentially a cosmologist whose views can be understood from their Ionian background. There was little or no mysticism about his teaching, and the stories

1 Studien zu Pythagoras, Philolaos und Platon (Erlanger Beiträge z. Sprach- und Kunstwiss., Bd. X), Nürnberg 1962.

${ }^{2} \mathrm{Pp} .146-340$.

${ }^{3}$ Col. I7I-268, 277-300. The contributions of H. Dörrie on "Der nachklassische Pythagoreismus", ibid., col. 268-277, and van der Waerden on "Die Schriften und Fragmente des Pythagoras", ibid., Suppl. Io, I965, col. $843^{-864}$, are of less immediate concern here.

${ }^{4}$ (Philosophical Texts and Studies, Vol. 12), Assen 1966.

5 Pythagoras and early Pythagoreanism (Phoenix, Suppl. Vol. 7), Toronto 1966. 
told later about Pythagorean life and science are largely fabrications. Philip's work is not likely to become as influential as the others, but he has undoubtedly made some points that should be taken into serious account.

In addition there have appeared recently several books and articles on particular problems concerning the Pythagoreans and on more peripheral questions. $^{1}$

I cannot attempt here to survey all the different views of recent research on early Pythagoreanism. But I shall try to discuss, mainly on the basis of the above-mentioned works, some points that have, or may have, some bearing on mysticism-however this term may be defined.

To begin with, there is strong evidence for the existence of a Pythagorean sect or brotherhood in some Greek cities of South Italy, from the days of Pythagoras (that is, the latter part of the 6th century) until the middle of the ${ }^{\text {th }}$ century, ${ }^{2}$ probably with a revival in the time of Archytas of Tarentum in the middle of the 4 th century B. C. If there was a sect, there was probably a system of doctrines. And if there was a system of doctrines, it is reasonable to try to reconstruct the system by a "synthetical" approach, as Guthrie, van der Waerden and de Vogel have tried to do. Guthrie in my opinion succeeds best in presenting a Pythagorean system that makes sense, both historically and philosophically. A reconstruction is of course in this case particularly liable to anachronism and subjectivity, considering the character

1 From the $x 960$ s the following may be mentioned: E. Brock, "Die Philosophie des Pythagoras", Anmuaire de la Soc. Suisse de Philos. 23, I963, pp. 29-50.

W. Burkert, "Hellenistische Pseudopythagorica", Philologus ro5, i96x, pp. r6-43, 226-246.

M. Détienne, Homère, Hésiode et Pythagore: poésie et philosophie dans le pythagorisme ancien (Coll. Latomus, Vol. LVII), Bruxelles 1962.

Idem, De la pensée religieuse à la pensée philosophique: la notion de daimon dans le pythagorisme ancien (Bibl.Fac. de Philos. E Lettres Univ. de Liège CLXV), Paris 1963.

K. H. Ilting, "Zur Philosophie der Pythagoreer", Archiv f. Begriffsgesch. 9, r964, pp. $103-\mathrm{I} 32$.

I. Lévy, Recherches esséniennes et pythagoriciennes (École pratique des Hautes Études, 4e Sect. Hist. \& philol. 3, Hautes Études du monde gréco-rom. I), Paris 1965.

Pitagorici, testimonianze e frammenti [early and classical], a cura di Maria Timpanaro Cardini (Biblioteca di studi sup. XXVIII), Fasc. I-III, Firenze 1958-r964.

The Pythagorean texts of the Hellenistic period, ed. by H. Thesleff (Acta Acad. Aboensis, Ser. A, Hum., Vol. $30 \mathrm{nr}$ r), Abo r 965. - Cf. also my Introd. (above).

${ }^{2}$ Philip's arguments (pp. $24 \mathrm{ff}$.) against the assumption of a sect are not convincing. 
of our sources. But it is useful to have at least a hypothetical frame into which the extremely heterogeneous doctrines of the doxography can be fitted, and by which they can perhaps be tested.

One of the difficulties with assuming a system of Pythagorean doctrines is that the views of the school may have developed or changed in the course of time, and that there may have occurred factional splits within. it. In fact this is probably what happened, and it may partly account for the confused statements of later traditions. These are very complicated questions in which little agreement has been reached so far. However, the really crucial problems concern the development of Pythagorean cosmology and mathematics in classical times-the rôle and doctrines of Hippasos, Philolaos and Archytas in particular, and their possible influence on Plato's cosmology and mathematics-and such questions are not of immediate interest here. And the Pythagorean "dissenters" of whom stories were current later-the most famous being Hippasos who was supposed to have discovered mathematical incommensurability - are unanimously said to have been mathematicians or "scientists". There is little or no evidence of a development or a differentiation of Pythagorean religious, mystical or ethical beliefs in the $5^{\text {th }}$ century. Indeed, a sect is likely to be conservative in such matters.

Some statements in our sources refer to a division of the sect into mathematikoi and akousmatikoi. The mathematikoi are usually taken to mean the "scientists", and the akousmatikoi the orthodox religious adherents. von. Fritz ${ }^{1}$ gives a more elaborate explanation; but at any rate linguistic reasons seem to me to indicate that the terms were not coined before the latter part of the $5_{\text {th }}$ century, after the dispersion of the school. Perhaps the akousmatikoi were the more orthodox forerunners of the so-called "Pythagorists" of

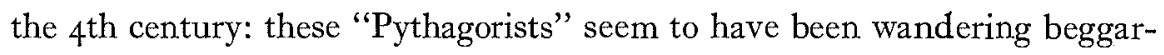
philosophers who practised asceticism and rituals of a probably diluted Pythagorean kind.2 They interest us merely as a symptom of the disintegration of the original school.

Owing to the confusion of Pythagorean and Platonic doctrines in Plato's

1 Col. $2 \times 9-224$.

2 References in my Introd., p. $5 \mathrm{I}$.

6-694455 Hartman 
Academy, ${ }^{1}$ there grew up, after Plato, a new manner of interpreting Pythagorean cosmology and mathematics. This new interpretation centred around the fundamental opposites One and Two, taken as symbols of the Limited and the Unlimited and of Odd and Even; further, the derivation of the universe and its elements from the geometrical concepts Point $(=$ One), Line (=Two), Triangle, and Pyramid; and to some extent it introduced astral religion. Burkert has argued at length ${ }^{2}$ that such interpretations should be kept apart from a reconstruction of early Pythagoreanism. Yet, I believe, they should not be neglected: they may contain a core of original doctrine.

For early Pythagoreanism Aristotle's account constitutes an important source, as many scholars, and now especially Philip, have pointed out. But Philip certainly underrates the significance of the later sources, especially those which may derive from Herakleides of Pontos, Aristoxenos, Dikaiarchos, and Timaios of Tauromenion, who had personal connections with the so-called "last Pythagoreans" of the $4^{\text {th }}$ century. Aristotle was not interested in Pythagoreanism as a doctrinal system. For a more full reconstruction than can be attempted at the present state of our knowledge, we need every scrap of evidence, the platonizing as well as the non-Platonic, however contorted by bias or by misleading interpretation it may be.

Our sources on the whole agree about three points in Pythagoras' teaching, the early date of which need not be doubted: (r) All is number; (2) the universe (or nature of things) is constituted by a harmony of opposites (this at least can be inferred from many statements and hints); and (3) the soul is immortal and subject to rebirth.

It is more difficult to make out how much was involved in these doctrines.

(I) "All is number" probably implies the generalization of the empirical fact that things are measurable and commensurable in terms of number (indeed a discovery with remarkable consequences for Western civilisation), together with some speculative thought about the apparent "mysticism" of numerical combinations, number Io for instance: its mystical Pythagorean name tetraktys looks early, and the term refers to the fact that $10=\mathbf{I}+2+3+$

1 This confusion is also reflected in the Hellenistic pseudo-Pythagorean literature (Pythag. Texts, ed. Thesleff) which has not been studied from this angle so far.

${ }^{2}$ Esp. pp. $74-85$. 
$+4 . .^{1}$ To the early Pythagoreans "all was number" in the even more concrete sense that a certain minimum number of pebbles can be arranged so as to represent the shape of a thing, as for instance stars in a constellation seem to represent an animal. We are told of Pythagoreans (especially one called Eurytos) who tried to make out the number representative of each thing, such as "man" or "horse", and also abstract concepts such as "justice" or "marriage". This indicates, as Burkert rightly argues, ${ }^{2}$ that the doctrine "all is number" does not admit advanced interpretation. But it is perhaps the most original doctrine of Pythagoreanism.

(2) The doctrine of a universal "harmony of opposites" is also known from Herakleitos. ${ }^{3}$ In fact the problem of opposites occupied practically all preSocratic philosophy. Guthrie ${ }^{4}$ has referred to Zoroastrian dualism as one possible source. However, the early Pythagorean implications of the word harmonia are somewhat obscure: it is not originally a musical term; it means just "fitting together". Probably it points in the same direction as the word kosmos in the sense of a "beautiful order of things", which Pythagoras is said to have introduced. ${ }^{5}$ Aristotle gives a table of Io fundamental Pythagorean opposites, beginning with Limited/Unlimited, Odd/Even, One/Plurality, which seem to have been taken as somehow generating each other. The table is not necessarily due to secondary systematization (though some scholars including Burkert think so): 6 at any rate the number Io is typical here.

(3) The doctrines on the soul are certainly of central importance. Philolaos the Pythagorean is said to have held that the soul is a harmony (of different parts), and Guthrie accepts this view as old; 7 but it may have been a development of an older conception, such as the idea that the soul is, or should be, "in harmony" with kosmos. At any rate there is enough evidence to indicate that the early Pythagoreans believed the air to be "full of souls or daimons". 8

\footnotetext{
${ }^{1} \mathrm{Cf}$. the above-mentioned speculations about the four geometrical concepts in the post-Platonic tradition.

2 Pp. 35-37.

3 Vors. 22 B 5 I. See the discussion by Guthrie, History of Greek Philosophy, I, pp. $435-449$.

${ }^{4}$ Pp. 25 I ff.

5 Though he hardly "invented" this sense. Cf. Burkert, pp. $68 \mathrm{ff}$.

${ }^{6}$ Arist. Met. 986 a 23-b 8. Burkert, pp. 45-46.

7 Vors. $44 \mathrm{~A} 23$. Guthrie, pp. 309-312.

${ }^{8}$ Anon.Alex. 32 (Pythag. Texts ed. Thesleff, p. 236. I 5 ff.); cf. Burkert, pp. r63 f.
} 
This archaic conception fits well in with the doctrine of metempsychosis which Pythagoras undoubtedly taught.

The ultimate origins of the belief in metempsychosis need not bother us here. But it would be of considerable interest to know whether Pythagoras took it over from Greeks or non-Greeks, because if it can be proved that he had direct contacts with non-Greeks of the East or North (and if, for instance, there is any truth in the story that he had as a slave a Thracian sage, ${ }^{1}$ ) we can safely widen our hypothetical frame for Pythagoreanism. von Fritz ${ }^{2}$ argues that Pythagoras was the first to introduce the metempsychosis doctrine in Greece, but I cannot see that he has proved this point. The interrelations of Orphism and Pythagoreanism are still highly controversial. I am inclined to think that there were in fact Orphics who taught metempsychosis in Pythagoras' lifetime, ${ }^{3}$ and that Orphism and Pythagoreanism independently reflect beliefs current in Greece in the late archaic age.

Regarding Burkert's view of Pythagoras the shamanist, Philip's objection ${ }^{4}$ that Pythagoras made no soul-journeys is certainly to the point. It is probably true that Burkert over-emphasizes this aspect. Pythagoras was no shaman proper. He was only influenced by the vaguely shamanistic trends of his age. It is not clear whether Pythagoras himself claimed to possess supernatural powers, but he was early credited with such powers. ${ }^{5}$

Pythagoras was an eclectic. I find it of essential importance to stress, as Guthrie and Philip have done, the nearly contemporary evidence given by Herakleitos: ${ }^{6}$ Pythagoras, says Herakleitos, was a polymath like Hesiod, Xenophanes, and Hekataios. This fact will help us a bit further.

For Pythagorean demonology, see Détienne's above-mentioned work of 1963 which gives, however, a rather optimistic reconstruction.

${ }^{1}$ Zalmoxis, according to Hdt.4.95 f. On Zalmoxis, see Burkert, esp. pp. I37 ff.

2 Col. I9I.

3 The Orphic Teletai, which seem to have included the metempsychosis doctrine, were current as "ancient" poems in Athens towards the end of the 5th century B.C. (Ar. Ran. 1032, cf. Eur. Hipp. 952-954). It is reasonable to identify them with the Teletai which, according to Suda s.v. Orpheus (Vors. I A I, ultimately perhaps Epigenes, an early Hellenistic antiquarian), were fathered on Orpheus by Onomakritos (about 5 го в.C.).

${ }^{4}$ P. $16 \mathrm{I}$.

${ }^{5}$ References in Burkert, passim. See esp. the passages collected in Vors. 14. 7.

${ }^{6}$ Vors. 22 B 40. Cf. Guthrie, p. I57, and Philip, p. $177 \mathrm{f}$. 
The metempsychosis doctrine usually involves cathartic religion, rules for purification of the soul in order to achieve higher incarnations. We have in fact ample evidence of such rules in Pythagoreanism. Many are included in the heterogeneous mass of sayings and prescripts called the Pythagorean akousmata (also symbola) which were collected in the $4^{\text {th }}$ century B.C., and of which we have a fair number of examples, ${ }^{1}$ such as:

What are the Isles of the Blessed? Sun and Moon.

The sea is tears of Kronos.

Friendship is equality.

The wisest is number.

The holiest is the leaf of mallow.

To abstain from beans (the prescript of abstaining from flesh does not occur explicitly among the akousmata, but it is well attested anyway).

Not to stir the fire with a knife.

Not to wear a narrow ring.

Not to make water or stand on one's nail-parings or hair-trimmings.

To roll up one's bedclothes on rising and smooth out the imprint of the body.

Some of the akousmata are remarkably picturesque, even poetic. Many are obviously very ancient taboo prescripts and probably have a ritual significance. Some give glimpses of ethics or cosmology. It is evident that here, too, there has occurred an accretion of spurious material, not to speak of the rationalistic or allegorical interpretations of later authors. But still, and with regard to Pythagoras' eclecticism, it seems likely that a considerable part of the akousmata were coined, or adopted from elsewhere, by Pythagoras himself, and that this was the kind of teaching to which the akousmatikoi adhered. The akousmata would thus constitute the earliest direct evidence of Pythagorean doctrine. It is to some extent hazardous to use them for a reconstruction of the details of early Pythagorean religion, cosmology, and ethics. But at any rate they indicate three very important things: ( $\mathrm{I}$ ) the teaching of Pythagoras was esoteric, "mysterious", and alluded to hidden truths; it is possible that a re-examination of all the extant akousmata would throw some light on the technique of Pythagorean "mystification"; (2) the teaching was transmitted orally in a sententious form; and (3) the content of this teaching was to some extent at least ritualistic and of considerable "primitivity" as

${ }^{1}$ References in Burkert, pp. I $5 \circ$ ff. Some interesting observations can also be found in M. P. Nilsson, Gesch. d.gr. Religion, Bd. I (Hdb.d.Alt.wiss. V:2: I), München I94I, pp. $665^{-669}$. 
comparad with, say, Eleatic philosophy. All this agrees better with Burkert's view of Pythagoras than with de Vogel's to take two extremes.

Yet, as Herakleitos said, Pythagoras was a polymath. How did he assimilate all the disparate ideas so far discussed? Guthrie ${ }^{1}$ brings them into a sensible pattern by emphasizing the doctrine of "kinship of all life". This doctrine is ascribed to Pythagoras by Porphyry in a passage (V. Pyth. 19) which probably derives from Dikaiarchos, and it also occurs in Empedokles (Vors. 3I B iro al.) who was acquainted with Pythagoreanism. As "life" has to be taken in a large sense, including kosmos (which "breathes", according to some doxographers), ${ }^{2}$ the idea of a "kinship of all life" would serve to connect the metempsychosis doctrine and its rituals with the ideas "all is number" and "all is a harmony of opposites". Perhaps it is appropriate to call the conception of universal kinship or sympathy "essentially magical", as Guthrie does. ${ }^{3}$ Pythagoras surely did not invent it himself. It came to him from the same obscure sources that provided him with the metempsychosis doctrine and the cathartic or taboo-like akousmata. But in association with the tremendous discovery of a numerical order inherent in the nature of things ${ }^{4}$ and the feeling that all opposites somehow "fit together" constructively, the idea of universal kinship must have acted as a revelation. At least we can imagine it so.

If the outlines of the doctrinal system of early Pythagoreanism were approximately as I have sketched them here, the system as such implied a kind of mysticism: the secrets of a cosmic order revealed to a generalizing intuition.

It would of course be particularly important from the point of view of the history of mysticism to know for certain to what extent the ideas of contemplation of the Divine and "unio mystica" can be traced back to early Pythagoreanism. Among recent authors, Guthrie, R. Joly, and de Vogel ${ }^{5}$ have made a point of the Pythagorean doctrine of "assimilation to the Divine". ${ }^{6}$

1 Pp. $186 \mathrm{ff}$.

2 See Guthrie, pp. 276 ff.

${ }^{3}$ P. I 86.

4 Guthrie, p. 237.

${ }^{5}$ Guthrie, esp. pp. 2 ro ff.; R. Joly, Revue Belge de Philol. 42, I964, pp. 91-95; de Vogel, esp. p. 72 .

6 So-called homoiosis tôi theôi, but this term does not occur before Plato. Its Pythagorean counterpart may have been something like synharmoge tôi kosmôi, "fitting in with the order of the universe". 
There are strong indications that this idea is indeed early Pythagorean, and that Plato's vision of the philosopher's rising to union with kosmos (e.g. Rep. VI. $500 \mathrm{c}$ ) is inspired by Pythagorean conceptions. It is also probable that we can trust those sources that speak in general terms of a Pythagorean training programme which included, not only taboo rituals, mystical silence, strict askesis and cult practices such as the cult of the Muses, but also educational training in music (for "attuning" the soul to cosmic harmony), mathematics, and astronomy. ${ }^{1}$ This would all aim at the "assimilation to the Divine". But here again, I am sorry to say, the details remain obscure; and above all, there are no manifest traces of a Pythagorean ekstasis doctrine (though this question has not been adequately studied so far). Perhaps the "programme" was not very differentiated nor consistent as to its aims. However, its two aspects, passive contemplation and active training, are notable.

It is clear that the Pythagorean system on the other hand inspired to a more "rational" preoccupation with the so-called four mathemata, arithmetic, geometry, harmonics, and astronomy. ${ }^{2}$ I shall not discuss here the very controversial problems of the Pythagorean achievements in these fields, but shall refer only to three points:

(I) It seems likely that Pythagoras himself was particularly interested in music and made (empirical) discoveries in musical theory. But it is uncertain whether the famous idea of "the harmony of the spheres", taken as the music produced by the harmonic intervals of the heavenly bodies, is early Pythagorean. Most scholars think it is, but Burkert ${ }^{3}$ has expressed serious doubts.

(2) The Pythagoreans certainly speculated on some geometrical truths, probably including the so-called "theorem of Pythagoras". But, as van der Waerden implies, ${ }^{4}$ we should not credit the earliest Pythagoreans with demonstration in the Euclidean sense. At any rate the practical applications of the notorious theorem were known to the Babylonians centuries before Pythagoras.

1 The evidence has been collected by de Vogel, passim; but it is of very varying reliability. For "mystical silence" among the Pythagoreans, see Burkert, p. I62.

2 The ultimately Pythagorean origin of the quadrivium seems beyond question.

${ }^{3}$ Pp. $328 \mathrm{ff}$., followed by Philip, pp. $123 \mathrm{ff}$.

${ }^{4}$ Col. $288 \mathrm{f}$. 
(3) It is usually accepted nowadays, and van der Waerden ${ }^{1}$ has argued this in detail, that the early Pythagoreans believed in a cosmic year and a cyclic recurrence of everything. van der Waerden infers that the Pythagoreans must have been strict astrological fatalists. It could be objected however, that strict fatalism does not easily agree with purification in order to reach higher incarnations. The system, as we have reconstructed it, does not seem to admit it. If the Pythagoreans were astrologists at all (which I think is highly questionable) they probably made the well-known vague compromise between determinism and indeterminism, Fate and Free Will.

We have seen that Pythagoras' teaching had a "mystic" touch, in form as well as in content. Esotericism as such was nothing new in the Greek world: some of the mysteries had existed long before Pythagoras, and cult brotherhoods were common. It is customary to refer to the fact that the Italian soil was particularly fertile for chthonic mysteries. I believe, however, that the parallel between Pythagoreanism and the mysteries, like the parallel between Pythagoreanism and Orphism, should not be pressed too far. The Pythagorean sect was centred around its Master (autos epha, "he said", referring to Pythagoras, became proverbial), it worked with little or no mythology, and it combined ritual katharsis with a revelation of intellectual or intuitive truths to an extent unknown to the mystai or the Orphics. Roughly speaking the Pythagoreans appear to have aimed less at salvation for its own sake, than at happiness and salvation through wisdom. Though Pythagoras probably did not invent the term philosophia, as was later believed, ${ }^{2}$ he practised what was meant by it. The "mystic" form and content of Pythagoras' teaching may have owed to the Ionian philosophical tradition more than is usually realized: ${ }^{3}$ trends similar to Pythagoreanism are exhibited above all by Herakleitos, though he did not found a school.

Unfortunately we know next to nothing about the organization of the Pythagorean brotherhood. Their proverbial secrecy has here at least served its purpose. von Fritz ${ }^{4}$ sums up the little our sources tell us.

Apart from the akousmata, there are occasional early indications of the

1 Col. 289-296 with ref.

${ }^{2}$ Burkert, p. 58 .

${ }^{3}$ Except in some ways by Philip.

${ }^{4}$ Col. $219 \mathrm{ff}$. 
existence of a Pythagorean hieros logos, a Sacred Code of all their doctrines. These indications are responsible for a flood of pseudepigraphical writings from the Hellenistic age onwards. ${ }^{1}$ Delatte and Rostagni have attempted to reconstruct the early hieros logos as a hexameter poem, but their combinations have not met with approval by the majority of scholars. Of the authors considered here, only van der Waerden and de Vogel ${ }^{2}$ incline to accept them wholeheartedly. My personal view is, that if there was a supposedly early Pythagorean poem (which indeed is possible), it is not likely to have been written by a well-initiated Pythagorean, nor to have contained all the doctrines. The real hieros logos -if there was such a thing apart from the akousmata-was probably in prose, and transmitted orally. The earliest written pieces of Pythagorean doctrine by initiated Pythagoreans are the possibly authentic fragments of Philolaos' book on the nature of things from the last third of the $5^{\text {th }}$ century, ${ }^{3}$ and the fragments of Archytas' writings. ${ }^{4}$ Both authors are rather mathematikoi, and belong to the time after the dispersion of the original school. These fragments are of no direct interest here.

Much inventiveness has been used in attempts to trace the secret or mystical words and signs supposed to have been current among the early Pythagoreans. I have already referred to the tetraktys, which is undoubtedly old. Words such as kosmos and harmonia were possibly employed as key words with a pregnant sense. ${ }^{5}$ But the letter $Y$ as a symbol of the cross-roads of life (the so-called "littera Pythagorica") is clearly late. ${ }^{6}$ And de Vogel7 shows convincingly that the pentagram never was a specifically Pythagorean symbol.

A religious or "mystic" sect is likely to have an esoteric code of ethics. And considering in particular the Pythagorean doctrine of universal kinship, it is reasonable to trust the evidence collected by de Vogel ${ }^{8}$ according to which

${ }^{1}$ Pythag. Texts, ed. Thesleff. The first mention of a Pythagorean hieros logos occurs in Herodotus 2.8x.

${ }^{2}$ van der Waerden, $R E$ Suppl. ro, 1965, col. 850 f.; de Vogel, pp. I 1, 14, al. Cf. Thesleff, Introd., p. 107, and Pythag. Texts, pp. 1 $58-163$.

${ }^{3}$ Vors. 44 . The latest discussion of these controversial fragments is by Burkert, pp. $203 \mathrm{ff}$.

4 Vors. 47.

5 So were probably exartysis "equipment", epaphe "treatment (of the soul)", and especially the Doric word synharmoga "fitting in with"; cf. de Vogel, pp. I64 f., and the Greek index of my Pythag. Texts.

${ }^{6}$ Burkert, "Hellen. Pseudopythag." (above), p. 230.

${ }^{7}$ Pp. $28 \mathrm{ff} . \quad{ }^{8}$ Pp. $70 \mathrm{ff}$, and passim. 
the early Pythagoreans held friendship, gentleness and modesty in high esteem. To make a metaphysical point of such virtues (if this is what Pythagoras did) was really something new and remarkable in Greek thought. Later there were many stories current about the internal loyalty of Pythagoreans. I have already referred to the potentially educational aspects of the Pythagorean training "programme". It is further understandable that Pythagorean exclusiveness fostered aristocratic tendencies in those cities, such as Kroton, where the sect became politically dominant, and that these tendencies led to the violent democratic reactions towards the middle of the 5th century, which finished the early school. But crediting Pythagoras with an advanced exoteric ethical and even political doctrine, as de Vogel and (to some extent) Guthrie do, seems to me rather too generous. ${ }^{1}$ The picture of Pythagoras the educator and prophet, who preached the gospel of universal brotherhood, emancipation of woman, and eternal reward for tenacity, abstinence and law-abiding tolerance in this life, is, I think, an invention by later ages. It hardly took articulate form before the $4^{\text {th }}$ century B.c.

Of the external activities ascribed to the Pythagoreans by trustworthy authors, medicine is still to be mentioned. Burkert ${ }^{2}$ refers to the archaic complex shaman-medicine-man. It is indeed probable that Pythagorean medicine remained on a speculative stage, as the physiological fragments of Philolaos seem to indicate.

The study of Pythagoreanism is still in a flux, in spite of the very considerable amount of scholarship and imagination applied to it even in quite recent years. Because of the nature of the sources available to us, it is a question not only of reason, but also of intuition and temperament, where to put the emphasis, and how to construct the mosaic. By combining the criticism and industry of Burkert, von Fritz, and Philip, with the vision of Guthrie, van der Waerden, and de Vogel, and by repeated re-examinations of all the material and all the background phenomena, it may still be possible to come nearer to an objective truth about this remarkable sect. I hope this would be worth while doing. But then the history of the subjective truths, the history of the various conceptions of Pythagoreanism, still remains to be written. And it is perhaps here that mysticism rather should be looked for.

${ }^{1}$ Cf. my review of de Vogel's book in Mnem. S. IV, Vol. 2r, I968, pp. 298-300.

${ }^{2}$ Pp. 27I ff. 